\title{
Creating a New England Salt Marsh Sediment Profile: Methods and Implications for Climate Change Mitigation Strategies
}

\author{
Alexandra B. MacFarland ${ }^{1+}$, Taylor A. Templeton ${ }^{1}$, Hayley N. Schiebel ${ }^{1}$ \\ ${ }^{1}$ Center for Urban Ecology and Sustainability Suffolk University, Boston, MA, 02108 \\ +Corresponding author (amacfarland@su.suffolk.edu) \\ DOI: $10.47611 /$ jsr.v9i1.828
}

\section{$\underline{\text { ABSTRACT }}$}

Salt marshes and other blue carbon systems (mangroves, sea grasses) sequester large amounts of carbon primarily through sedimentation and therefore naturally aid in climate change mitigation. However, disturbances caused by anthropogenic activity (agriculture, ditching, invasive species, construction) are leading to New England salt marsh habitat destruction. The loss of this carbon sink could result in the system becoming a carbon source, potentially contributing to climate change rather than abating it. In this study, a sediment profile of a temperate New England salt marsh was created. Vernier sensors were used to collect both discrete sediment samples (soil pH) and in situ sediment samples (soil salinity, soil moisture, soil temperature) weekly for one year (June 2018 - June 2019) at the Neponset River Salt Marsh in Boston, Massachusetts. The objective was to observe seasonal variations in sediment between two locations dominated by different types of marsh vegetation (Spartina alterniflora and Spartina patens). Soil $\mathrm{pH}$ was determined to not seasonally differ at either location. Soil $\mathrm{pH}$ and temperature showed no difference between soils under different types of marsh vegetation. At both locations, soil salinity, soil moisture, and soil temperature were significantly different between each season. Additionally, soil moisture and salinity were significantly different between locations in the summer and autumn. This work shows how marshes may respond to future climate scenarios, particularly increased temperatures and increased sea-level.

\section{Introduction}

Salt marshes are important for a wide range of ecosystem services, including habitats for numerous species of fish, birds, and invertebrates (Deegan et al., 2012; Emery and Fulweiler, 2014). Salt marshes serve as a nursery to many species of fish and shell-fish that live there during the early stages of their lives and are dependent on the ecosystem for food and shelter (Weis and Butler, 2009). Marsh plants provide shelter for spawning and protect the juveniles of various other species (both with commercial and ecological importance), including blue crabs (Callinectes sapidus), croakers (Micropogonias undulates) and flounders (Paralichthys dentatus; Weis and Butler, 2009). For example, bluefish (Pomatomus saltatrix) spawn out in the ocean, but the juveniles (snappers) move into estuaries in the spring and remain there through the summer, feasting on the smaller fish that live there. Salt marshes additionally serve as a shield and protect coastal areas from storms and floods (Weis and Butler, 2009). They are important shoreline stabilizers because they can take the brunt of storm waves, buffering the shoreline from flood and storm damage (Weis and Butler, 2009). A common source of flood damage occurs following storms when runoff from the land hits the coastal plain (Weis and Butler, 2009). Marshes are natural sponges that can absorb much of this runoff, reducing its impact on coastal environments and real estate (Weis and Butler, 2009). Furthermore, established marsh grasses are highly effective against erosion (Weis and Butler, 2009). The roots and rhizomes of these plants help the sediment cohere 
and consolidate, resulting in less erosion in vegetated areas (Weis and Butler, 2009). When marshes are removed, the effects of storms on coastal communities are much more severe and devastating, and therefore costlier (Weis and Butler, 2009).

Most importantly, salt marshes are blue carbon systems. Blue carbon refers to the climate change mitigation benefits offered by the biogeochemical processes performed by coastal wetlands systems (salt marshes, mangroves, seagrasses and other tidal wetlands; Emmett-Mattox and Crooks, 2014). These systems capture large amounts of carbon through photosynthesis and/or by trapping sediments and natural debris in their complex root systems (Howard et al., 2017). Blue carbon systems occupy $0.2 \%$ of the ocean surface, but between $50 \%$ and $90 \%$ of all coastal wetland carbon (vegetation-dependent) is found in blue carbon system soils (Howard et al., 2017). Tidal inundation aids in carbon sequestration by keeping the soil submerged, inhibiting microbial action, and slowing decomposition such that carbon accumulated in soils remains relatively stable (Howard et al., 2017). These systems also accumulate carbon transported by rivers and tides in the form of vegetation and sediment for adjacent ecosystems (Howard et al., 2017).

Unlike dry terrestrial systems (i.e., forests), the content of soil carbon does not reach equilibrium, meaning that the dry terrestrial system will not be able to accept any more carbon at some point, yet salt marsh systems are able to continuously take in more carbon via accretion (Chmura, 2009). The long-term rates of carbon accumulation in soils of temperate, tropical, and boreal forests from chronosequences (set of ecological sites that share similar attributes but represent different ages) of 8,000-10,000 years ranged between 0.7 and $13.1 \mathrm{~g} \mathrm{C} \mathrm{m}^{-2} \mathrm{yr}^{-1}$ (Mcleod et al., 2011). Even with these three systems combined the carbon sequestration rate of just the salt marsh soils $\left(210 \mathrm{~g} \mathrm{C} \mathrm{m}^{-2} \mathrm{yr}^{-1}\right)$ was much higher than the temperate, tropical, and boreal forests carbon sequestration rate (Mcleod et al., 2011; Chmura., 2009). This suggests that salt marshes play a critical role in the global sequestration of carbon that would otherwise remain as atmospheric carbon dioxide $\left(\mathrm{CO}_{2}\right)$ and exacerbate climate change (Chmura et al., 2003; Mcleod et al., 2011).

The current disruption of coastal ecosystems through physical human activities may result in a switch from them being a net sink to instead a net source of carbon (Mcleod et al., 2011). Blue carbon sinks (inclusive of salt marshes) lose about $0.7-7.0 \%$ of their area annually (Mcleod et al., 2011) due to a number of anthropogenic forcings. The expansion of human populations along coastlines during the past century has led to the alteration and degradation of many salt marsh habitats (Koch and Gobler, 2009). The draining of marshes for land use, and the creation of fish or salt pounds are all processes that have altered, degraded, or destroyed salt marsh habitats (Koch and Gobler, 2009). A prominent form of New England salt marsh alteration is ditching (Koch and Gobler, 2009). This was prompted by an increase of mosquito-borne illness as ditches were designed to eliminate standing water in marshes, which is a required habitat for mosquito larvae (Koch and Gobler, 2009). It is estimated that $90 \%$ of salt marshes in the Northeastern United States were ditched during the twentieth century as a means of reducing mosquito populations (Koch and Gobler, 2009). An unintended consequence of this practice was the lowering of the marsh soil salinity, speculated by some to be responsible for the establishment of the invasive plant genus Phragmites over the native plant genus Spartina (Koch and Gobler, 2009). Recent assessments have suggested that about one-third of the total salt marshes have already been lost or degraded over the past several decades as a result of the aforementioned activities (Mcleod et al., 2011).

Anthropogenic climate change could also create conditions in which salt marshes become carbon sources versus carbon sinks. As Earth's atmosphere warms due to the trapping of heat by greenhouse gases released from the fossil fuel industry, ocean levels are both expanding due to thermal expansion and rising due to glacial melting. During the past 4,000 years, the elevation of New England salt marshes have mostly kept pace with sea-level rise with an average accretion rate of $0.11 \mathrm{~cm}_{\text {year }}^{-1}$ in New England (Carey et al., 2015) as the increased hydroperiod provides greater opportunity for suspended sediment to settle and denser vegetation provides greater capacity to trap the sediment (Chmura, 2013). However, the ability of marshes to maintain their elevation in the face of accelerated sea-level rise remains uncertain as projected increases in global sea-levels range from 0.3 to $1.2 \mathrm{~m}$ by 2100 (Carey et al., 2015), and there is a threshold above which increased tidal submergence becomes a stress on marsh vegetation (Chmura, 2013). Saturated soils present challenges to nutrient uptake and drain plants stored energy, resulting in decreased production (Chmura, 2013). With this negative feedback comes continued deficit in marsh vertical acceleration, 
degradation of the marsh, and loss of the carbon sink (Chmura, 2013). Erosion of marsh soil could then result in shifts of carbon to other parts of the estuary, where it might be redeposited or even oxidized (combined chemically with oxygen), resulting in the return of the stored carbon to the atmosphere as $\mathrm{CO}_{2}$ (Chmura, 2013). The system would then be contributing to the amount of $\mathrm{CO}_{2}$ released into the atmosphere and could turn the salt marsh into a carbon source where it emits more carbon than it absorbs (Chmura, 2013).

Understanding seasonal variation in salt marsh sediment $\mathrm{pH}$, salinity, moisture, and temperature will aid in characterizing how these ecosystems may respond to climate change both directly in the soil and indirectly through plant functionality. For example, soil acidity is usually not a problem for most wetland soils because prolonged saturation and inundation tend to drive the $\mathrm{pH}$ toward neutrality ( $\mathrm{pH}=7$; Craft, 2000). In acidic soils $(\mathrm{pH}<7)$, microbial reduction of iron $(\mathrm{Fe})$ consumes $\mathrm{H}^{+}$and raises the $\mathrm{pH}$, while in basic soils $(\mathrm{pH}>7)$, the production of organic acids during anaerobic decomposition lowers the $\mathrm{pH}$ (Craft, 2000). Soil acidity indirectly inhibits plant growth by increasing concentrations of reduced Fe and manganese (Mn) to toxic levels for vegetation (Craft, 2000). In acidic soils, Mn and Fe toxicity have been reported for a variety of flood-intolerant terrestrial species (Craft, 2000). Microbial reduction in most wetland soils can lead to higher levels of $\mathrm{Mn}$ and Fe as compared to terrestrial soils and many wetland species have a higher tolerance for $\mathrm{Mn}$ and $\mathrm{Fe}$ than terrestrial species (Craft, 2000). In strongly acidic soils $(\mathrm{pH}<4), \mathrm{H}^{+}$and Al saturation of soil cation exchange sites leads to reduced $\mathrm{Ca}^{2+}$ uptake, reduced growth and mortality, and inhibited root elongation in marsh plants (Craft, 2000). An increase in atmospheric $\mathrm{CO}_{2}$ can lead to the acidification of ocean water by the creation of carbonic acid (Carey et al., 2015). As the tides inundate the salt marsh, slightly acidic water is absorbed by the sediment which can change the $\mathrm{pH}$ (Carey et al., 2015). Several macronutrients (nitrogen, sulfur, phosphorus) needed for plant growth are more readily available at a higher $\mathrm{pH}$. Thus, a lower $\mathrm{pH}$ could also cause these nutrients to become less soluble and affect marsh plant growth in addition to changing cation exchange site chemistry (Craft, 2000).

Climate change can also cause elevated marsh soil salinity both by sea-level rise and/or increased temperature (leading to drought conditions, increased evaporation, and therefore saltier sediment; Watson et al., 2016). Varying salinity can then change the marsh plant zonation (Watson et al., 2016). Investigation has shown that as the high tide increases in duration of flooding, the vegetation shifts from less salt tolerance species to more salt tolerant species (Watson et al., 2016). Higher temperatures leading to saltier soil can also displace marsh plants (Hughes et al., 2012). Spartina alterniflora (S. alterniflora) is known to be highly salt-tolerant but can experience salt stress at salinities less than 40 (Hughes et al., 2012). In a study during which S. alterniflora plants were subjected to two different salinity treatments (3-5 and 35-38) and soil drying treatments that lasted 8,16, and 24 days, the survival rate for S. alterniflora fell to below 30 percent during a combined treatment of elevated salinity and soil drying (Hughes et al., 2012).

Similarly, increases in temperature due to climate change will affect the amount of moisture in salt marsh sediment (Erwin, 2009). Increased temperatures may influence the elevational zonation of marshes as sea-level rises, increasing soil waterlogging and anoxia in low marsh habitats (Bertness and Ewanchuk, 2002). At higher elevations, marsh plants are potentially exposed to limiting hypersaline soil conditions that are the result of the evaporation of marsh porewater (Bertness and Ewanchuk, 2002). At lower elevations, higher soil salinities do not occur because frequent tidal flooding routinely flushes salt accumulations from the marsh, whereas at higher marsh elevations, rain and runoff limit the development of hypersaline soil conditions (Bertness and Ewanchuk, 2002). The decrease in soil moisture can lead to increased concentrations of salinity due to increased evaporation, and therefore, similar vegetation shifts outlined above for sediment soil salinity could occur (Bertness and Ewanchuk, 2002).

Finally, interactions between soil temperature and nutrient supply have considerable importance in salt marshes with possible increases or decreases in the ability of these systems to sequester carbon. Increased $\mathrm{CO}_{2}$ and subsequently warmer temperatures tend to increase rates of marsh accretion and presumably the ability of marshes to survive sea-level rise (Kirwan and Mudd, 2012). Sea-level rise also leads to more mineral sediment deposition, which influences the elevation of coastal salt marshes and might enhance their ability to sequester carbon (Kirwan and Mudd, 2012). However, soil organic matter decomposition is the breakdown of plant and animal detritus through leaching and decomposer activity and is a primary mechanism for carbon loss in salt marshes (Stagg et al., 2017). It is well- 
documented that decomposition rates increase with increasing soil temperature and that carbon will decompose at a faster rate than the system can absorb (Stagg et al., 2017). This could lead to more $\mathrm{CO}_{2}$ being released into the atmosphere and could reverse the wetland carbon sink (Kirwan et al., 2014).

This study aims to create a sediment profile of an urban, temperate salt marsh in New England. A detailed salt marsh sediment profile of this kind does not exist for a salt marsh of this nature and will help to better understand how temperate marshes may respond to climate change affects, particularly increased temperatures and sea-level rise. A combination of both weekly discrete and in situ sampling was completed using Vernier sensors to test soil pH, soil salinity, soil moisture, and soil temperature from June 2018 to June 2019 to observe seasonal trends. Samples were obtained from two locations with varying dominant vegetation (S. alterniflora and Spartina patens (S. patens)) to quantify any changes in soil parameters by vegetation coverage and/or distance from the main water channel in the marsh as well.

\section{Methods}

\section{Study site}

The Neponset River Salt Marsh $\left(42.277309^{\circ},-71.045837^{\circ}\right)$ is $1.1 \times 10^{6} \mathrm{~m}^{2}$ in area and comprised of three dominant plant species: S. alterniflora dominates the low marsh, while $S$. patens and the invasive reed Phragmites Australis ( $P$. australis) dominate the high marsh. Approximately $29 \%$ of the total surface area is below the Mean Lower Low Water (MLLW) mark and is normally covered by water with no vegetation and/or mudflat area (Schiebel et al., 2018). While sediment analysis has not yet been conducted at this study site, typical temperate salt marsh sediment is composed of peat with water content ranging between 30 and 60\% (Redfield, 1972) and sediment organic carbon values ranging between 0.05 and $0.15 \mathrm{~g} \mathrm{~cm}^{-3}$ (Artigas et al., 2015).

\section{Sample collection}

A suite of four measurements were taken every week for one year in triplicate (June 2018 through June 2019) at low tide: soil $\mathrm{pH}$, salinity, moisture and temperature. These variables were measured in a S. alterniflora-dominated area as well as a S. patens-dominated area. To measure soil pH, 100 grams of surface sediment was collected from the study site and returned to the laboratory. Within 24 hours of collection, soil samples were dried in a Fisher Isotemp 200 Series oven at $50^{\circ} \mathrm{C}$ for one week. 50 grams of dried sediment sample was placed into a 250 -mL beaker with 100 $\mathrm{mL} 0.01 \mathrm{M} \mathrm{CaCl}_{2}$. A stirring rod was used to stir the sample once every three minutes for fifteen minutes to ensure homogeneity. The mixture settled for five minutes to ensure that a layer of sediment sunk to the bottom of the beaker and the liquid solution with suspended sediment was on top. A Vernier $\mathrm{pH}$ sensor was calibrated using a standard solution. Sample readings were done using the same LabQuest 2 device in the laboratory in triplicate.

To measure soil salinity, 50 grams of surface marsh sediment was placed into $100 \mathrm{ml}$ of Milli-Q (MQ) water (pre-prepared and taken into the field). A stirring rod was used to stir the solution once every three minutes for fifteen minutes to ensure homogeneity. A Vernier conductivity probe was set to $0-20000 \mathrm{uS} / \mathrm{cm}$ salinity range and calibrated using sodium chloride $1000 \mathrm{uS} / \mathrm{cm}$ solution. Sample readings were done using the same LabQuest 2 device in the field in triplicate.

Vernier LabQuest 2 in situ probes and a LabQuest 2 device were implemented to measure both soil moisture and soil temperature. First, a small amount of sediment was removed with a shovel. The soil moisture probe was inserted horizontally into the sediment and completely covered with the removed sediment. It remained there until the reading stabilized $( \pm 0.2 \%)$ and measurements were taken in triplicate. The soil temperature probe was inserted vertically at the same location. It remained there until the reading stabilized $\left( \pm 0.2{ }^{\circ} \mathrm{C}\right)$ and measurements were taken in triplicate.

\section{Statistical analyses}


R software was utilized to perform a one-way Analysis of Variance (ANOVA) and a Kruskal-Wallis rank sum test. The ANOVA test was done to compare changes in the four variables (temperature, moisture, salinity, $\mathrm{pH}$ ) seasonally between locations (S. patens and S. alterniflora). The ANOVA test is used to test the differences in the mean of three or more variables and assumes that the variables tested are normally distributed (Zarr, 1999). The Kruskal Wallis rank sum test was used in conjunction with the ANOVA test, as it tests under the assumption that the data is not normally distributed (Zar, 1999). Furthermore, a t-test and Wilcoxon rank sum test were also preformed to compare each season (summer, autumn, winter, spring) individually between the two locations for each of variable. The t-test tested for differences in means between the two variables. However, the t-test assumes that the variables tested are normally distributed, whereas the Wilcoxon rank sum test, used in conjunction with the t-test, analyzes under the assumption that the data is not normally distributed (Zar, 1999).

\section{Results and Discussion}

\section{Soil pH}

Soil $\mathrm{pH}$ was the only factor that was not different between the four seasons and between both locations (p-value $>$ 0.05). $\mathrm{pH}$ additionally had the most variability within each season (Figure 1).
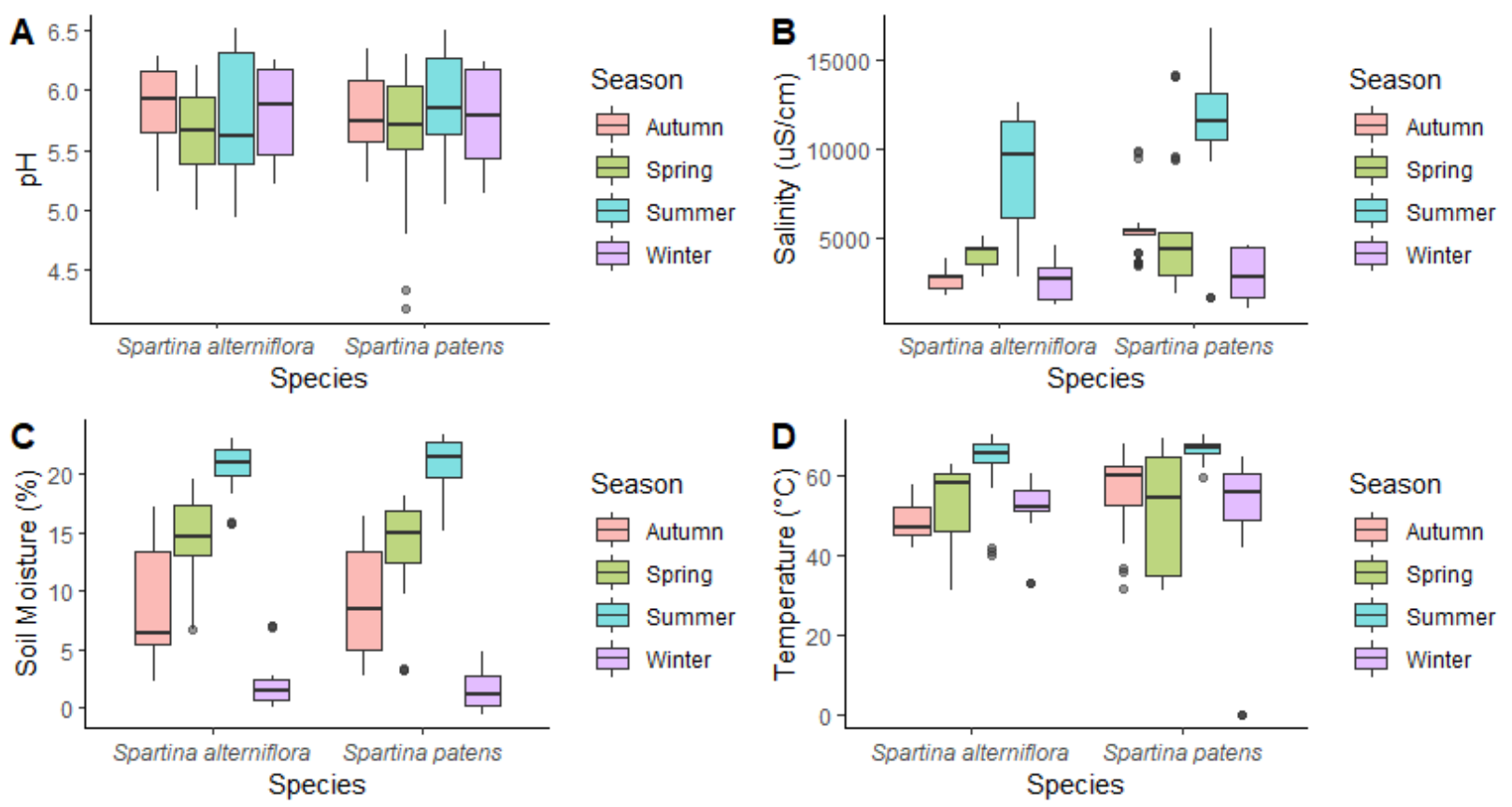

Figure 1. Seasonal soil pH (A), salinity (B), moisture (C), and temperature (D), measurements by vegetation coverage/location: S. patens in the high marsh and S. alterniflora in the low marsh.

Soil $\mathrm{pH}$ did not differ significantly among seasons regardless of vegetation coverage/location and was the most variability in the summer (Figure 1A). pH was observed to have the highest values in the summer at both locations. Saravanakumar et al. (2008) defined the physicochemical characteristics of sediment and water, as well as the textural aspects of sediments in western mangroves of Kachchh-Gujarat, west coast of India, for the duration of two years from 1999-2000. Sediment and surface water samples were collected every month in three different mangrove sites. $\mathrm{pH}$ was measured by a calibrated $\mathrm{pH}$ pen ( $\mathrm{pH}$ ep-3 model), and soil $\mathrm{pH}$ was further determined by adopting the method of Jackson (1958). They found that sediment $\mathrm{pH}$ was high in summer and low during monsoon seasons, potentially due to redox changes in the sediments and water column apart from the influence of freshwater (Ramanathan, 1997). 
Other studies have found no change in pH across seasons. Portnoy and Giblin (1997) investigated biogeochemical effects of tidal restrictions at three New England salt marshes. The first site was a diked, seasonally flooded site in North Sunken Meadoe of Eastham, MA. The second site was a diked and drained site at the Herring River estuarine in Wellfleet, MA. The third site was also diked and drained and located at Pine Creek in Fairfeld, CT. Surface soil (45-cm depth) pH was measured monthly from May 1993 to October 1994 and there was little seasonal variation in $\mathrm{pH}$ in all three salt marshes. It was surmised that sulfide reduction and the production of bicarbonate consistently buffered $\mathrm{pH}$ to about 6.5 at these sites (Portnoy and Giblin, 1997). The data found at the Neponset River Salt Marsh found similar results (Figure 1A) with no difference in $\mathrm{pH}$ over the four seasons and can be assumed that the similar sulfide chemistry is providing a pH buffer in the marsh soil.

\section{Soil salinity}

Soil salinity was highest in summer regardless of vegetation coverage/location and lowest in winter with the most amount of variability in summer (Figure 1B). Autumn was higher than spring for S. patens but spring was higher than autumn for S. alterniflora. Soil salinity was not significantly different between locations in the winter and spring (pvalue $>0.05$ ). There was, however, a significant difference between locations in the summer and autumn ( $p$-value $<$ 0.05). Many studies have investigated seasonal variation in soil salinity using in situ sensors. Burdick et al. (2001) measured the soil salinity underlying S. patens, S. alterniflora, and P. australis plants at the Great Marsh in Rowley, Massachusetts. Arrays of wells at three different depths (5-20, 35-50, and 65-80 cm) were installed to collect interstitial soil salinity along the vegetation zonation pattern. Wells were sampled at low tide during the growing season over two years (Burdick et al., 2001). Soil salinity was lowest earlier in the growing season with deeper depths measuring most saline under natural hydrologic conditions. However, later in the growing season shallow depths were the most saline. In the Neponset River Salt Marsh, there was a significant difference in soil salinity among all four seasons, similarly with moisture being the highest in the summer (late growing season) and lowest in the winter and autumn (early growing season).

A more recent study done by Watson et al. (2016) investigated soil salinity at Coggeshall and Nag salt marshes in Prudence Island, Rhode Island. Watson et al. (2016) tested soil salinity from May through September in 2013 in porewater using a YSI sensor (Watson et al., 2016). Higher soil salinity levels were found in the lowest elevations suggesting that inundation plays a role in reducing organic matter production in $S$. patens because it increases sulfide and salinity levels that are detrimental to the plants. Higher soil salinity is expected at lower elevations given that it is exposed more to sea water as the tides move in and out (Watson et al., 2016). The study at Neponset River Salt Marsh measured soil salinity in different elevations: low elevation dominated by S. alterniflora and higher elevations dominated by S. patens. However, there was no significant different in soil salinity by vegetation coverage in this salt marsh, which is most likely due to how close the sampling locations were to each other (roughly 6 meters apart; Figure 1B).

\section{Soil moisture}

Soil moisture was lowest in the winter regardless of vegetation coverage/location and then increased in spring until reaching its highest in summer, where it then started to decrease again into autumn - autumn showing the most variation (Figure 1C). Outliers in winter were attributed to frozen sediment providing inaccurate readings. Soil moisture was not significantly different between locations in the winter and spring ( $\mathrm{p}$-value $>0.05$ ). There was, however, a significant difference between locations in the summer and autumn ( $\mathrm{p}$-value $<0.05$ ). Previous studies have investigated seasonal variation in soil moisture using in situ sensors as well. Lewis et al. (2014) investigated soil water moisture at the Salt Springs Run Tidal Estuary in Florida in December 2011. Soil cores were collected at each site and soil moisture was determined as a mass loss of drying (Lewis et al., 2014). They found that soils were wet at low tide as water accounted for $75-85 \%$ of total soil mass. These results differed from the ones obtained at the Neponset River Salt Marsh. The soil moisture content of the Neponset River Salt Marsh during the winter at both locations was around 
$50 \%$. A similar study to that in Florida by Lewis et al. (2014) was completed by Ewanchuk and Bertness (2003) at the Little River marsh in Wells, Maine. Soil moisture content was quantified by determining the difference between wet weight and dry weight of the soil core samples in 1998. Cores contained approximately $60 \%$ water $(57.21 \pm 7.45 \%$; Ewanchuk and Bertness, 2003). These moisture values were closer to that of the Neponset River Salt Marsh, revealing that geographic marsh location (i.e. New England versus Florida) does affect the soil moisture values (Figure 1C).

\section{Soil temperature}

Soil temperature did not vary between location/vegetation coverage regardless of season (p-value $>0.05$ ). Soil temperature was lowest in the winter regardless of vegetation coverage/location and then increased in spring until reaching its highest in summer, where it then started to decrease again into autumn - autumn showing the most variation (Figure 1D). The outlier depicts an unseasonably cold day.

Several studies have investigated seasonal variation in marsh soil temperature using in situ sensors. Bertness and Ewanchuk (2002) investigated two salt marshes in New England (Maine and Rhode Island) to examine the linkage between climate and interspecific plant interactions. Temperature data loggers were installed in vegetated and unvegetated plots at all sites. The temperature probes of the data loggers were attached to the sediment surface to measure sediment surface temperature (Bertness and Ewanchuk, 2002). The data loggers were deployed each year (1997-2000) during the last week of May and took soil surface temperature measurements every 5 minutes through the first week of August (end of growing season; Bertness and Ewanchuk, 2002). Once the growing season ended the data loggers were returned to the laboratory and the data was downloaded (Bertness and Ewanchuk, 2002). Soil temperature from the experimental plots revealed strong neighboring plant, regional, and inter-annual variation (Bertness and Ewanchuk, 2002). Daily mean soil surface temperature in unvegetated plots $\left(23.4 \pm 0.6{ }^{\circ} \mathrm{C}\right.$ Maine, $24.7 \pm 0.6{ }^{\circ} \mathrm{C}$ Rhode Island, pooled over years) were typically $2-3^{\circ} \mathrm{C}$ higher than in vegetated plots $\left(21.5 \pm 0.4{ }^{\circ} \mathrm{C}\right.$ Maine, $21.3 \pm 0.3{ }^{\circ} \mathrm{C}$ Rhode Island, pooled over years; Bertness and Ewanchuk, 2002). Soil temperature was generally cooler in the vegetated plots due to shading provided by plants (Bertness and Ewanchuk, 2002). This was unlike what was observed at the Neponset River Salt marsh, where the most vegetation, seen in spring and summer, had higher soil temperature compared to less vegetated seasons (autumn and winter). This could be due to the heat waves experienced in the summer during this study. Abnormally high atmospheric temperatures would correlate to warmer soil temperatures, and thus alter the overall average.

More recently, in a factorial S. patens warming field experiment, Gedan and Bertness (2010) recorded soil temperature hourly from May through August with iButton dataloggers $\left( \pm 0.1{ }^{\circ} \mathrm{C}\right.$, Maxim/Dallas Semiconductor, Dallas, TX) at the Narragansett Bay National Estuarine Research Reserve in Rhode Island. Warming treatments simulated climate change expected in New England $\left(1-3^{\circ} \mathrm{C}\right)$ at each plot and had large effects on soil temperature. Gedan and Betness (2010) found warmer soil temperatures in the summer compared to the other seasons. This supports the data found at the Neponset River Salt Marsh, with the soil temperature reaching a maximum in summer, decreasing through the autumn until reaching the minimum in winter, and then increasing again through the spring back to summer (Figure 1D).

\section{Future projections}

While acidification is already linked to lower low oxygen conditions, continual emissions of anthropogenic $\mathrm{CO}_{2}$ (i.e. an increase in ocean acidification) will further raise the partial pressure of seawater $\mathrm{CO}_{2}$ in hypoxic (none/low oxygen) regions in a nonlinear manner (Melzner et al., 2013). Estuarine salt marsh systems are specifically projected to be affected in this way through future acidification (Wang and Cai, 2004). A lower $\mathrm{pH}$ would result in less dissolved oxygen, most likely becoming a limiting factor for plant respiration. Therefore, an increase in acidity may result in a loss of vegetation, further leading to an overall change in sediment properties.

Additionally, as temperatures rise from an increase in $\mathrm{CO}_{2}$ emissions, evaporation will increase and the hydrologic cycle will intensify, resulting in a greater occurrence of storm events (also altering salinity, moisture, and temperature values; Hartig et al., 2002). Concurrent to this, as sea-level rises, the amount of flooding with each storm 
could increase, along with heightened waves, causing more erosion (Hartig et al., 2002). Salt marshes will become progressively more susceptible to erosional impacts from said storms and rise of sea level (Hartig et al., 2002). When vegetation is exposed to extended periods of submergence, the amount of oxygen to its roots becomes greatly reduced (Orson et al., 1985). This exposure would lead to water-logged soil and vegetation death (Orson et al., 1985). Due to this factor, the marsh will experience a decrease in plant biomass, leading to a decrease of in situ organic sediment sources and a simultaneous decrease in sediment trapping capability (Orson et al., 1985). Therefore, sea-level rise has the potential to increase soil moisture to the point where the vegetation could die, again resulting in an overall change of sediment properties.

As a whole, increased $\mathrm{CO}_{2}$ emissions (acidification, temperature increase, sea-level rise) will negatively affect the chemistry of salt marsh sediment, both directly and indirectly. This will lead to less suitable conditions for vegetation, which will increase erosion and loss of soil. This will further lead to a decline in health of the ecosystem, and vital functions will be lost.

\section{Conclusion}

Salt marshes and other blue carbon systems (mangroves, sea grasses) sequester large amounts of carbon primarily through sedimentation. This naturally aids in climate change mitigation. However, the degradation of these ecosystems through anthropogenic disturbances may have detrimental side effects, and in the face of climate change, there are many unknowns in terms of how these systems may respond. In this study, a combination of both weekly in situ and discrete sampling was completed using Vernier sensors to test soil $\mathrm{pH}$, salinity, moisture, and temperature from June 2018 to June 2019 to observe seasonal and location (by vegetation coverage) differences. Soil $\mathrm{pH}$ was determined to not seasonally differ at either location $(\mathrm{p}>0.05)$. Furthermore, $\mathrm{pH}$ as well as temperature, showed no difference between soils under different types of marsh vegetation $(\mathrm{p}>0.05)$. At both locations, soil salinity, soil moisture, and soil temperature were significantly different between each season $(\mathrm{p}<0.05)$. Additionally, soil moisture and salinity were significantly different between locations in the summer and autumn $(\mathrm{p}<0.05)$. Future studies would include a longer time series and more frequent recording (i.e., daily instead of weekly) to better characterize these trends.

The anthropogenic increase of $\mathrm{CO}_{2}$ emissions (causing acidification, temperature increase, and sea-level rise) will negatively affect the chemistry of salt marsh sediment, both directly and indirectly. Acidification is predicted to create/exacerbate hypoxic conditions. Also, as temperature rises, evaporation will increase and the hydrologic cycle will intensify, resulting in a greater occurrence of storm events. This will lead to less suitable conditions for vegetation, which will increase erosion and loss of soil. This will further lead to a decline in health of the ecosystem, and vital functions will be lost.

\section{Acknowledgements}

Partial funding for this research was provided by the Suffolk Faculty Research Assistance Program. The authors additionally thank Katherine Lawlor for partial sample collection. There is no conflict of interest associated with this research.

\section{References}

Artigas F, Shin J.Y., Hobble, C., Marti-Donati, A., Schäfer, K.V.R., Pechmann, I. 2015. Long term carbon storage potential and $\mathrm{CO}_{2}$ sink strength of a restored salt marsh in New Jersey. Agric For Meteorol 200:313-321.

Bertness, M., Ewanchuk, P.J. 2002. Latitudinal and climate-driven variation in the strength and nature of biological interactions in New England salt marshes. Oecologia, 132, 392- 401. 
Burdick, D.M., Bauschaum, R., Holt, E. 2001. Variation in soil salinity associated with expansion of Phragmites australis in salt marshes. Environmental and Experimental Botany 46: 247- 261.

Carey, J.C., Moran, S.B., Kelly, R.P., Kolker, A.S., Fulweiler, R.W. 2015. The declining role of organic matter in New England salt marshes. Estuaries and Coasts, 40, 626-639.

Chmura, G.L. 2013. What do we need to assess the sustainability of the tidal salt marsh carbon sink? Ocean Coast Manage, 83, 25- 31 .

Chmura, G.L. 2009. Tidal Salt Marshes. In: Laffoley, D.d'A. \& Grimsditch, G. (eds). The management of natural costal carbon sinks. IUCN, Gland, Switzerland.

Chmura, G.L., Anisfeld, S.C., Cahoon, D.R., Lynch, J.C. 2003. Global carbon sequestration in tidal, saline wetland soils. Global biogeochemical cycles, 17.

Craft, C.B. 2000. Co-development of wetlands soils and benthic invertebrate communities following salt marsh creation. Wetlands Ecology and Management, 8, 197.

Deegan, L.A., Johnson, D.S., Warren, R.S., Peterson, B.J., Fleeger, J.W., Fagherazzi, S, Wollheim, W.M. 2012. Coastal eutrophication as a driver of saltmarsh loss. Nature, 490, 388-392.

Emery, H.E., Fulweiler, R.W. 2014. Spartina alterniflora and invasive Phragmites australis stands have similar greenhouse gas emissions in a New England marsh. Aquatic Botany, 116, 83-92.

Emmett-Mattox, S., Crooks, S. 2014. Special Focus: Coastal Blue Carbon. Coastal Blue Carbon, 36, 5.

Erwin, K.L. 2009. Wetlands and global climate change: the role of wetland restoration in a changing world. Wetlands Ecol Manag, 17, 71-84.

Ewanchuk, P.J., Bertness, M.D. 2003. Recovery of a northern New England salt marsh plant community from winter icing. Oecologia, 136, 616-626.

Gedan, K.B., Bertness, M.D. 2010. How will warming affect the salt marsh foundation species Spartina patens and its ecological role? Oecologia, 164, 479- 487.

Hartig, E., Gornitz, V., Kolker, A., Mushacke, F., Fallon, D. 2002. Anthropogenic and Climate-Change Impacts on Salt Marshes of Jamaica Bay, New York City. Wetlands, 22 (1), 71-89.

Howard, J., Sutton-Grier, A., Herr, D., Kleypas, J., Landis, E., Mcloed, E., Pidgeon, E., Simpson, S. 2017. Clarifying the role of coastal and marine systems in climate mitigation. Frontiers in Ecology and the Environment, $15,42-50$.

Hughes, A., Wilson, A., Morris, J. 2012. Hydrologic variability in a salt marsh: Assessing the links between drought and acute marsh dieback. Estuarine, Coastal and Shelf Science, 111, 95- 106.

Jackson, M.L. 1958. Soil chemical analysis. Prentice Hall, Englewood Cliffs, NJ. p. 498. 
Kirwan, M.L., Guntenspergen, G.R., Langley, J.A. 2014. The temperature sensitivity of organic matter decay in tidal marshes. Biogeosciences, 11, 4801- 4808.

Kirwan, M.L., Mudd, S.M. 2012. Response of salt-marsh carbon accumulation to climate change. Nature, 489, 550553.

Koch, F., Gobler, C.J. 2009. The effects of tidal export from salt marsh ditches on estuarine water quality and plankton communities. Estuaries Coasts, 32, 261- 275.

Lewis, D.B., Brown, J.A., Jimenez, K.L. 2014. Effects of flooding and warming on soil organic matter mineralization in Avicennia germinans mangrove forests and Juncus roemerianus salt marshes. Estuarine, Coastal and Shelf Science, 139, 11- 19.

Mcleod, E., Chmura, G.L., Bouillon, S., Salm, R., Björk, M., Duarte, C.M., Lovelock, C.E., Schlesinger, W.H. Silliman, B.R. 2011. A blueprint for blue carbon: toward an improved understanding of the role of vegetated coastal habitats in sequestering CO2. Frontiers in Ecology and the Environment, 9, 552-560.

Melzner, F., Thomsen, J., Koeve, W., Oschlies, A., Gutowska, M., Bange, H., Hansen, H., Kortzinger, A. 2013. Future ocean acidification will be amplified by hypoxia in coastal habitats. Mar Biol., 160, 1875-1888.

Orson, R., Panageotou, W., Leatherman, S. 1985. Response of Tidal Salt Marshes of the U.S. Atlantic and Gulf Coasts to Rising Sea Levels. Journal of Coastal Research, 1(1), 29-37.

Portnoy, J.W., Giblin, A.E. 1997. Effects of historic tidal restrictions on salt marsh sediment chemistry. Biogeochemistry, 36: 275-303.

Ramanathan, A.L. 1997. Sediment characteristics of the Pichavaram mangrove environment, southeast coast of India. Ind. J. Mar. Sci., 26, 319-322.

Redfield, A.C. 1972. Development of a New England salt marsh. Ecological Monographs, 42, 201- 237.

Saravanakumar, A., Rajkuma, M., Sesh Serebiah, J., Thivakaran, G. A. 2008. Seasonal variations in physico-chemical characteristics of water, sediment and soil texture in arid zone mangroves of Kachchh-Gujarat. Journal of Environmental Biology, 29(5), 725-732.

Schiebel, H., Gardner, G., Wang, X., Peri, F., Chen, R. 2018. Seasonal Export of Dissolved Organic Matter from a New England Salt Marsh.Journal of Coastal Research, 34, 939-954.

Stagg, C. L., Schoolmaster, D. R., Krauss, K.W., Cormier, N., Conner, W.H. 2017. Causal mechanisms of soil organic matter decomposition: deconstructing salinity and flooding impacts in coastal wetlands. Ecol-

ogy, 98, 2003- 2018.

Wang, Z., Cai, W.J. 2004. Carbon dioxide degassing and inorganic carbon export from a marsh dominated estuary (the Duplin River): a marsh CO2 pump. Limnol Oceanogr 49:341-352.

Watson, E.B., Szura, K., Wigand, C., Raposa, K.B., Blount, K., Cencer, M. 2016. Sea-level rise, drought and the decline of Spartina patens in New England marshes. Biological Conservation, 196, 173-181.

Weis, J.S., Butler, C.A. 2009. Salt marshes: a natural and unnatural history. New Jersey: Rutgers University Press. 254.

Zar, Jerrold. Biostatistical Analysis. Prentice-Hall, Inc., 1999. Print. 